\title{
PROFIL PERSALINAN PADA USIA $\geq 35$ TAHUN DI RSUP PROF. DR. R. D. KANDOU MANADO
}

\author{
${ }^{1}$ Vidi Y. Y. Pontoh \\ ${ }^{2}$ Hermie M. M. Tendean \\ ${ }^{2}$ Eddy Suparman
}

\author{
${ }^{1}$ Kandidat Skripsi Fakultas Kedokteran Universitas Sam Ratulangi \\ ${ }^{2}$ Bagian Obstetri Ginekologi Fakultas Kedokteran Universitas Sam Ratulangi Manado \\ Email: vidi_11_184@yahoo.com
}

\begin{abstract}
Childbirth at age $\geq 35$ years has a high degree of risks. High blood pressure, excessive body weight, diabetes, as well as complicated labor can be found in pregnancy and childbirth at age $\geq 35$ years. This study aimed to obtain the profile of childbirth at age $\geq 35$ years at Prof. Dr. R. D. Kandou Hospital Manado. This was a descriptive retrospective study using the medical record and birth attendants at The Obstetrics and Gynecology Department from 1 January to 31 December 2014. There were 249 cases of childbirth at age $\geq 35$ years of 3106 total labors. Most of the mothers at age $\geq 35$ years had parity of $2-4$ (66.26\%), spontaneous labor (60.64\%), babies with cephalic presentation (70.28\%), and weight $2500-$ $<4000$ grams.
\end{abstract}

Keywords: labor, age $\geq 35$ years, incidence

\begin{abstract}
Abstrak: Persalinan pada usia $\geq 35$ tahun mempunyai risiko tinggi. Tekanan darah tinggi, kelebihan berat badan, diabetes, serta persalinan yang lebih sulit dan lama merupakan masalah yang dapat ditemui di kehamilan dan persalinan pada usia $\geq 35$ tahun. Penelitian ini bertujuan untuk mendapatkan profil persalinan pada usia $\geq 35$ tahun di RSUP Prof. Dr. R. D. Kandou Manado. Penelitian ini menggunakan metode deskriptif retrospektif melalui rekam medik dan buku partus di bagian Obstetri dan Ginekologi RSUP Prof. Dr. R. D. Kandou Manado periode 1 Januari - 31 Desember 2014. Terdapat 249 kasus persalinan pada usia $\geq 35$ tahun dari 3106 total persalinan. Sebagian besar ibu berusia $\geq 35$ tahun berada pada paritas $2-4(66,26 \%)$ dan lebih sering lahir dengan presentasi letak kepala (70,28\%). Umumnya persalinan terjadi spontan (60,64\%) denan berat badan bayi $2500-<4000 \mathrm{~g}$.
\end{abstract}

Kata kunci: persalinan, usia $\geq 35$ tahun, insidensi

Persalinan merupakan serangkaian proses pengeluaran hasil konsepsi oleh ibu, dimulai dengan his persalinan yang berdampak pada perubahan serviks secara progresif dan diakhiri dengan lahirnya plasenta. ${ }^{1}$ Proses persalinan dipengaruhi oleh bekerjanya tiga faktor yang berperan yaitu kekuatan mendorong janin keluar (power) yang meliputi his (kekuatan uterus), kontraksi otot dinding perut, kontraksi diafragma, dan ligamentum action, faktor lain adalah faktor janin (passenger) dan faktor jalan lahir (passage). Apalagi ketiga faktor ini dalam keadaan baik, sehat, dan seimbang, maka proses persalinan akan berlangsung secara normal. Namun apabila salah satu dari ketiga faktor tersebut mengalami kelainan, misalnya keadaan yang menyebabkan kekuatan his tidak adekuat, kelainan pada bayi atau kelainan jalan lahir maka persalinan tidak dapat berjalan secara normal. $^{2}$

Di era modern seperti saat ini, banyak 
perempuan memutuskan untuk menunda kehamilan pertamanya hingga berusia lebih dari 35 tahun. Namun hamil di usia yang sudah tidak muda lagi memiliki risiko yang lebih tinggi. Setelah berusia 35 tahun, risiko perempuan untuk memiliki bayi dengan kelainan kromosom semakin tinggi. Kelainan kromosom antara lain trisomi 13, 18, dan 21. Trisomi 21 dikenal juga dengan istilah Down syndrome. ${ }^{3}$

Bagi sebagian besar wanita, persalinan merupakan pengalaman yang baik, tanpa komplikasi dan berharga. Sekitar 85\% wanita melahirkan bayi pertama dengan normal, dan meningkat 95\% jika persalinan sebelumnya normal. Namun, dari hasil survey ditemukan setiap tahun wanita di negara-negara berkembang mengalami komplikasi yang serius selama proses persalinan sebanyak 12-15\% dari seluruh ibu hamil. ${ }^{4}$ Di Kanada, proporsi kelahiran pertama terjadi di kalangan wanita berusia $>30$ tahun telah meningkat dalam 20 tahun terakhir. Dan saat ini, $11 \%$ kelahiran pertama terjadi pada wanita beusia $\geq 35$ tahun. kecenderungan untuk menunda hamil dan melahirkan anak juga terjadi di Eropa Barat, Australia, Selandia Baru, dan Amerika Serikat. ${ }^{5}$ Pada penelitian di RSU Prof. Dr. R. D. Kandou Manado 20012002, didapatkan 46430 persalinan, diantaranya 686 kehamilan pada usia 35 tahun atau lebih (14,81\%). Jumlah ini cenderung meningkat dari 305 tahun 2001 (2353 kehamilan) menajdi 381 dari 227 kehamilan di tahun $2002{ }^{6}$

Setiap hari di Amerika Serikat, hampir 200 orang wanita berusia 35 tahun atau lebih tua melahirkan bayi pertama mereka. ${ }^{7}$ Umumnya, wanita yang menunggu untuk hamil sampai usia 35 tahun cenderung lebih berhati-hati merencanakan kehamilan mereka. Hal ini secara tidak langsung memberikan keuntungan. Dengan merencanakan kehamilan, wanita dapat meningkatkan kesehatan mereka di masa prakonsepsi, dan dapat mulai mempersiapkan diri untuk menjadi orang tua. ${ }^{8}$ Dilihat dari kondisi psikologis dan mentalnya, wanita usia 30-an lebih siap menjadi seorang ibu. Namun ada pula beberapa tantangannya. Terkait dengan kondisi kesehatan yang menurun, maka kualitas sel telur pun kelainan/cacat bawaan pada janin akibat kelainan kromosom. Selain itu, mulai muncul berbagai keluhan kesehatan saat hamil, seperti kelebihan berat badan, tekanan darah tinggi, diabetes yang sering mempengaruhi proses persalinan. ${ }^{7,9,3}$

\section{METODE PENELITIAN}

Penelitian yang dilakukan bersifat deskriptif retrospektif Penelitian ini dilakukan di bagian BLU RSUP Prof. Dr. R. D. Kandou Manado Penelitian dilakukan pada periode 1 Januari - 31 Desember 2014 dan memenuhi kriteria inklusi, yaitu: insiden, paritas, usia kehamilan, jenis presentasi, jenis persalinan, berat badan lahir.

\section{HASIL PENELITIAN}

Tabel 1. Insiden jumlah persalinan

\begin{tabular}{cccc}
\hline Tahun & $\begin{array}{c}\text { Jumlah } \\
\text { persalinan }\end{array}$ & $\begin{array}{c}\text { Jumlah } \\
\text { persalinan pada } \\
\text { usia } \geq 35 \text { tahun }\end{array}$ & $\%$ \\
\hline 2014 & 3106 & 249 & 8,02 \\
\hline
\end{tabular}

Tabel 2. Distribusi persalinan menurut paritas

\begin{tabular}{ccc}
\hline \multirow{2}{*}{ Paritas } & \multicolumn{2}{c}{ Persalinan $\geq 35$ Tahun } \\
\cline { 2 - 3 } & Jumlah & $\%$ \\
\hline P 1 & 33 & 13,25 \\
P 2 - 4 & 165 & 66,26 \\
P $\geq 5$ & 51 & 20,49 \\
Total & 249 & 100 \\
\hline
\end{tabular}

Tabel 3. Distribusi persalinan menurut usia kehamilan

\begin{tabular}{ccc}
\hline \multirow{2}{*}{ Usia Kehamilan } & \multicolumn{2}{c}{ Persalinan $\geq 35$ Tahun } \\
\cline { 2 - 3 } & Jumlah & $\%$ \\
\hline$\leq 36$ minggu & 34 & 13,65 \\
$37-40$ minggu & 156 & 62,65 \\
$\geq 41$ minggu & 59 & 23,70 \\
Total & 249 & 100 \\
\hline
\end{tabular}


Tabel 4. Distribusi persalinan menurut jenis presentasi

\begin{tabular}{ccc}
\hline Jenis & \multicolumn{2}{c}{ Persalinan $\geq 35$ Tahun } \\
\cline { 2 - 3 } Presentasi & Jumlah & $\%$ \\
\hline Letak kepala & 175 & 70,28 \\
Letak & 57 & 22,89 \\
sungsang & & \\
Letak lintang & 17 & 6,83 \\
Total & 249 & 100 \\
\hline
\end{tabular}

Tabel 5. Distribusi persalinan menurut jenis persalinan

\begin{tabular}{ccc}
\hline Jenis & \multicolumn{2}{c}{ Persalinan $\geq 35$ Tahun } \\
\cline { 2 - 3 } Persalinan & Jumlah & $\%$ \\
\hline Spontan & 151 & 60,64 \\
Seksio & 74 & 29,72 \\
Sesarea & & \\
Ekstraksi & 24 & 9,64 \\
Vakum & & \\
Total & 249 & 100 \\
\hline
\end{tabular}

Tabel 6. Distribusi persalinan menurut berat badan lahir

\begin{tabular}{ccc}
\hline Berat Badan & \multicolumn{2}{c}{ Persalinan $\geq 35$ Tahun } \\
\cline { 2 - 3 } Lahir $(\mathrm{g})$ & Jumlah & $\%$ \\
\hline$<2500$ & 52 & 20,88 \\
$2500-<$ & 168 & 67,47 \\
4000 & & \\
$\geq 4000$ & 29 & 11,65 \\
Total & 249 & 100 \\
\hline
\end{tabular}

\section{BAHASAN}

Dari hasil penelitian secara deskriptif periode 1 Januari - 31 Desember 2014 di BLU RSUP Prof. Dr. R. D. Kandou Manado. Pada Tabel 1, diperoleh jumlah persalinan tahun 2014 sebanyak 3106 kasus persalinan dan persalinan pada usia $\geq 35$ tahun dengan jumlah 249 kasus (8,02\%). Jumlah persalinan pada penelitian ini mengalami penurunan jika dibandingkan dengan penelitian yang dilakukan Meyclin tahun 2011 di RSUP Prof. Dr. R. D. Kandou Manado dengan jumlah sebanyak 846 kasus persalinan pada usia $\geq 35$ tahun dari total 4155 persalinan. ${ }^{10}$

Pada Tabel 2 berdasarkan paritas persalinan pada usia $\geq 35$ tahun ditemukan pada paritas 1 yaitu 33 kasus (13.25\%), paritas 2 - 4 sebanyak 165 kasus (66.26\%), dan paritas $>5$ sebanyak 51 kasus (20.49\%). Hasil penelitian ini sebanding dengan hasil penelitian yang didapatkan pada penelitian di RSUP dr. M. Jamil Padang 2010, dimana pada usia $\geq 35$ tahun paritas terbanyak yaitu pada paritas 1-3 dengan 161 kasus. ${ }^{10}$ Pada penelitian Yuli di RS dr. Moewardi Surakarta tahun 2006, kelahiran pertama (primipara) kelompok kasus terdapat sebanyak 47.1\%, dibandingkan dengan penelitian sekarang lebih sedikit yaitu $13.25 \%{ }^{11}$

Pada Tabel 3, didapatkan persalinan pada usia $\geq 35$ tahun dilihat dari usia kehamilan terbanyak pada kehamilan aterm yaitu 156 kasus (62.65\%). Pada kehamilan < 36 minggu (preterm) terdapat 34 kasus (13.65\%), dan kehamilan > 41 (postterm) terdapat 59 kasus (23.70\%). Dari hasil penelitian ini menunjukkan bahwa kebanyakan wanita yang bersalin pada usia $\geq 35$ tahun berada dalam rentang waktu kehamilan yang normal, yaitu $37-40$ minggu.

Berdasarkan Tabel 4, jenis presentasi yang banyak di temukan pada persalinan pada usia $\geq 35$ tahun, yaitu janin dengan letak kepala dengan jumlah 175 kasus (70.28\%), letak sungsang 57 kasus (22.89\%), letak lintang 17 kasus (6.83\%). Pada penelitian primigravida tua yang bersalin di RSU Prof. Dr. R. D. Kandou Manado tahun 1997 - 2001 juga didapatkan bahwa presentasi janin umumnya letak kepala (90\%), sungsang (14\%), dan letak bokong (2\%). ${ }^{6}$

Tabel 5 terdapat 3 jenis persalinan, yaitu spontan, seksio sesarea, dan ekstrasi vakum. Dari tabel tersebut menunjukan jenis persalinan pada usia $\geq 35$ tahun kehamilan secara spontan yang terbanyak dengan jumlah 151 kasus (60.64\%), secara seksio sesarea ditemukan 74 kasus (29.72\%), dan secara ekstraksi vakum 24 kasus (9.64\%). Berdasarkan penelitian yang dilakukan di RSUP dr. M. Jamil Padang 2010, didapatkan hasil lebih banyak dimana persalinan pada usia $\geq 35$ tahun paling dilakukan dengan cara spontan, yaitu sebanyak 205 kasus, sedangkan jenis persalinan dengan tindakan 
sebanyak 141 kasus. ${ }^{25}$ Dari hasil penelitian Yuli ditemukan lebih banyak kasus persalinan secara seksio sesarea dari penelitian yang didapatkan, yaitu sebanyak 451 kasus (35.82\%) dan dari ekstraksi vakum sebanyak 51 kasus (0.04\%). ${ }^{11}$

Menurut Sarwono, besarnya penyebab kelahiran bayi dengan berat lahir rendah dapat dilihat dari faktor janin dan faktor ibu. Faktor janin meliputi kehamilan ganda dan hidramion dimana keadaan air ketuban mebihi jumlah normal (2 liter). Sedangkan faktor ibu meliputi usia ibu, usia kehamilan, paritas, pemeriksaan kehamilan, status nutrisi dan penyakit yang diderita ibu. $^{12}$

Pada Tabel 6 dapat dilihat bahwa berat badan lahir yang paling banyak ditemukan pada persalinan pada usia $\geq 35$ tahun adalah bayi dengan kelompok berat 2500 $<4000$ gram yaitu sebanyak 168 kasus (67.47\%). Namun, untuk jumlah kasus berat badan lahir rendah $<2500$ gram pada penelitian ini sedikit, yaitu 52 kasus (20.88\%), dan jumlah berat badan lahir tinggi >4000 gram ditemukan 29 kasus (11.65\%). Dari penelitian Karwati di RSUD Kota Bandung tahun 2007, kelompok berat badan lahir rendah didapatkan seimbang dari penelitian sekarang, yaitu dengan jumlah 60 kasus (25.75\%). ${ }^{13}$

Kehamilan resiko tinggi merupakan suatu kehamilan dimana jiwa dan kesehatan ibu serta janin atau bayi yang dilahirkan terancam. Dari definisi tersebut dapat dijelaskan bahwa setiap kehamilan dengan adanya faktor resiko tertentu akan menyebabkan wanita tersebut dan bayinya menghadapi morbiditas dan mortalitas yang tinggi selama kehamilan, saat persalinan dan setelah melahirkan (nifas).

Untuk menentukan suatu kehamilan resiko tinggi, dilakukan penilaian terhadap wanita hamil untuk menentukan apakah dia memiliki keadaan atau cirri-ciri yang menyebabkan dia ataupun janinnya lebih rentan terhadap penyakit atau kematian (keadaan atau ciri tersebut disebut faktor resiko). Faktor resiko bisa memberikan suatu angka yang sesuai dengan beratnya resiko. $^{14}$

Dewasa ini terdapat kecenderungan wanita yang hamil atau melahirkan pada usia 35 tahun atau lebih. Peningkatan ini kemungkinan oleh karena semakin berkembangnya bidang pendidikan dan lapangan kerja bagi kaum wanita sehingga lebih banyak wanita yang terlambat berkeluarga. $^{12}$

Kehamilan pada usia yang terlalu muda dan tua termasuk dalam kriteria kehamilan resiko tinggi dimana keduanya berperan meningkatkan morbiditas dan mortalitas pada ibu maupun janin. ${ }^{15}$

Kelahiran dan persalinan mungkin menjadi lebih terbatas, karena usia menempatkan pada resiko tinggi. Lain dari itu, mulai muncul berbagai keluhan kesehatan saat hamil, seperti tekanan darah tinggi dan diabetes yang terjadi selama proses persalinan. ${ }^{7,9}$ Faktor ini cenderung terjadi sering dilakukan dengan cara seksio sesarea diusia 35 ke atas. ${ }^{6}$

\section{SIMPULAN}

Dari hasil penelitian dan bahasan dapat disimpulkan bahwa yang tertinggi dari segi paritas yaitu P2-4, janin dengan letak kepala, jenis persalinan secara spontan dengan berat badan lahir bayi yang paling banyak yaitu $2500-<4000 \mathrm{~g}$.

\section{DAFTAR PUSTAKA}

1. Varney H. Varney's Midwifery. Sudbury, Massachusetts: Jones and Bartlett Publishers, 2006.

2. Cunningham FG. Obstetri Williams (Edisi XXI). Jakarta: EGC, 2005.

3. Kartika U. Hamil Sehat di Atas Usia 35 Tahun. 2013 [cited 2014 Sept 15]. Available from: http://health.kompas.com/read/2013/0 7/23/0957570/Hamil.Sehat.di.Atas.Us ia.35.Tahun

4. WHO. Indonesia Reproductive Health Profile 2003. Jakarta: Ministry of Health Republic of Indonesia, 2003.

5. Johnson A, Tough S. Delayed ChildBearing. J Obstet Gynaecol Can. 2012;34 (1):81.

6. Masengi GA. Perbandingan Kejadian Penyulit Persalinan Pada 
Primigravida Tua Dengan Primigravida Usia Reproduksi Sehat di RSUP Prof. Dr. R. D. Kandou Manado Periode 2007-2009 [Skripsi]. Jakarta: Universitas Pembangunan Nasional Veteran, 2011.

7. Curtis GB. Kehamilan di Atas Usia 30. In: Satyanegara S (editor), Asih Y (alih bahasa). Jakarta: Arcan, 1999.

8. Mikail B. Hamil di Usia 30 Tahun Tak Selamanya Beresiko. 2012. [cited 2014 Sept 18]. Available from: http://health.kompas.com/read/2012/0 2/29/11380796/Hamil.di.Usia.30.Tah un.tak.Selamanya.Berisiko

9. Hamil Sukses dan Prima di Usia 30-an. [cited 2014 Sept 18]. Available from: http://www.ayahbunda.co.id/Artikel/k ehamilan/gizi+dan+kesehatan/hamil.s uskes.dan.prima.di.usia.30an/001/001 /924/41/2
10.Sibuea M. Profil Persalinan Pada Usia > 35 Tahun di BLU RSU Prof. Dr. R. D. Kandou Manado Periode 1 Januari-31 Desember 2011 [Skripsi]. Manado: Universitas Samratulangi, 2011.

11.Kehamilan Resiko Tinggi. [cited 2015 Jan 12]. Available from: http://eprints.undip.ac.id/15334/1/TE SIS_YULI_KUSUMAWATI.pdf

12.Shehadeh A. Elderly Primigravida and Pregnancy Outcome. J Res Med Sci. 2002;9(2):8-11.

13.Sarwono. Ilmu Kebidanan. YB-PSP. Jakarta: EGC, 2002.

14.DeCherney HA. Current Obstetrics and Gynecologic Diagnosis and Therapy. India: Mc Graw Hill, 2003; p 216-7.

15. Mochtar R. Kasus-kasus resiko tinggi. In: Lutan D, editor. Sinopsis Obstetri (Ed 2). Jakarta: EGC, 1989.; p.217-23. 